\title{
Utenlandske leger i norsk psykiatri - behov for en mentorordning?
}

\begin{abstract}
BAKGRUNN I likhet med i andre vestlige land har antallet utenlandske leger $ø$ kt kraftig i Norge i de senere år. Manglende språkferdigheter og kulturelle forskjeller kan skape utfordringer. Hensikten med denne studien var å undersøke hva leger i spesialisering i psykiatri mente om en mentorordning for utenlandske leger og hvordan en slik støtteordning eventuelt burde utformes.
\end{abstract}

MATERIALE OG METODE Data ble innsamlet gjennom fokusgruppeintervjuer med leger i spesialisering i psykiatri. 24 norske og 16 utenlandske leger deltok i totalt fem fokusgrupper. Tematisk analyse ble brukt som metode.

RESULTATER Et gjennomgående funn var forskjellen i de norske og de utenlandske legenes syn på behovet for en mentorordning. De utenlandske legene opplevde få språk- og kulturrelaterte problemer, mens deres norske kolleger erfarte til dels at det var betydelige problemer. Videre kom det frem holdningsmessige barrierer mot en mentorordning hos de utenlandske legene og også ulikt syn på organiseringen av en slik ordning, spesielt når det gjaldt frivillighet og mentor som likemann (horisontal organisering) versus mentor som overordnet (vertikal organisering).

FORTOLKNING Ulike holdninger til innføring av en mentorordning skyldtes dels forskjellig syn på problemets omfang og dels ulike normer og verdier hos de utenlandske og de norske legene. Vi foreslår at flere former for mentorordning prøves ut gjennom et pilotprosjekt der de utenlandske legene trekkes aktivt med.

De siste 10-15 årene har det vært en sterk økning i antall utenlandske leger i Norge, til nå (2014) ca. 3900 eller en seksdel av alle leger i yrkesaktiv alder. Samme utvikling har man sett i USA, Canada, Australia og de fleste vesteuropeiske land (1). Ifølge årsmeldingen for Den norske legeforening (2) gjaldt $38 \%$ av alle spesialistgodkjenninger i 2013 utenlandske statsborgere. Av dem som fikk spesialistgodkjenning i psykiatri i 2013, var $46 \%$ utenlandske statsborgere.

Legers ulike språk- og kulturbakgrunn representerer en stor ressurs i en etnisk sammensatt pasientpopulasjon og kan tilføre helsetjenesten verdifull kunnskap og nye perspektiver (3). Samtidig vil svak språkkompetanse hos legen og kulturrelaterte misforståelser kunne føre til problemer visà-vis kolleger og pasienter. Språk- og kulturrelatert kommunikasjonssvikt mellom lege og pasient vil kunne svekke kvaliteten på helsetjenesten. Behovet for kulturforståelse er stort $(4,5)$. Til tross for problemets omfang og alvorlighetsgrad er det internasjonalt gjort begrenset forskning på området.

I 1997 foretok Norsk overlegeforening en kartlegging og opinionsmåling blant norske avdelingsoverleger og utenlandske leger i spesialisering ved sykehusene (6). Undersøkelsen viste at hver fjerde overlege syntes det var språkproblemer $\mathrm{i}$ forbindelse med de utenlandske legenes arbeid, mens disse legene selv rapporterte signifikant færre problemer. Videre opplevde rundt halvparten
(49\%) av avdelingsoverlegene på avdelinger med mange leger med ikke-skandinavisk bakgrunn at det oppsto problemer som følge av mangelfull kjennskap til norsk kultur og kulturelle forskjeller i normer og verdier. Tre av fire utenlandske leger opplevde derimot ikke slike problemer. Ett av tiltakene som ble anbefalt i denne studien, var støttenettverk for utenlandske leger (6). En slik ordning er fortsatt ikke implementert.

Internasjonale studier anbefaler ulike tiltak for å lette utenlandske legers profesjonelle og personlige orienteringsprosess ( $7-10)$. Mentorordninger («mentor» i betydningen veileder, fadder) har vist seg å kunne bidra til personlig vekst, større jobbtilfredshet og bedret effektivitet $\mathrm{i}$ arbeidet. Ordningen er ett av flere tiltak som foreslås for å bidra til en vellykket integrering (8-12). Sentrale temaer i veiledningen er kommunikasjonsproblemer, synet på legerollen, kollegiale relasjoner og kulturbaserte forskjeller i verdisyn. Hjelp i tilegnelsen av arbeidsprosedyrer og arbeidsrutiner samt støtte til sosial integrering via kollegialt fellesskap står også sentralt $(9,10,13,14)$.

Det finnes få studier der man spesifikt har undersøkt mentorordninger for utenlandske leger i faget psykiatri (15). Det har til nå ikke vært gjort slike studier i Norge - verken innen psykiatri eller andre medisinske fag. Hensikten med vår studie var å undersøke interessen for en mentorordning for utenlandske leger i spesialisering i psykiatri i

\author{
Morten Sandbu \\ uxsamn@ous.no \\ Seksjon for akuttpsykiatri \\ Oslo universitetssykehus, Ullevål \\ Anne Kamps \\ Lovisenberg DPS \\ Lovisenberg Diakonale Sykehus

\section{Valjbona Preljevic} \\ Avdeling for psykosomatisk medisin \\ Klinikk for kirurgi og nevrofag \\ Oslo universitetssykehus
}

\section{Cecilie Javo}

Samisk nasjonalt kompetansesenter - psykisk helsevern og rus (SANKS) Finnmarkssykehuset

Engelsk oversettelse på www.tidsskriftet.no

> Se lederartikkel side 1104

\section{HOVEDBUDSKAP}

De utenlandske legene var mindre positive til en mentorordning enn det de norske legene var

De utenlandske legene opplevde i liten grad språk- og kulturproblemer

Kulturbaserte holdninger synes å ha påvirket legenes syn på både innføring og utforming av en mentorordning 


\section{RAMME 1}

\section{Undersøkelsesmetode}

Fokusgrupper $(16,17)$

Fokusgrupper er uformelle gruppeintervjuer hvor diskusjonen gir innsikt i deltakernes holdninger og forståelse knyttet til et tema

En fordel med fokusgruppe som metode er at den gir rom for gruppedynamikk, slik at temaet belyses fra flere vinkler og man kan oppdage uforutsette forhold

\section{Tematisk analyse (18)}

Innebærer å kategorisere utsagn fra gruppeintervjuer tematisk og identifisere meningsmønstre på tvers av gruppeintervjuene

Meningskategoriseringen danner utgangspunkt for fortolkning av resultatene

Norge og hvordan den best kan la seg gjennomføre.

\section{Materiale og metode}

Vi anvendte som undersøkelsesmetode fokusgrupper og tematisk analyse, med leger $\mathrm{i}$ spesialisering innen psykiatri som informanter (ramme 1) (16-18). Det har vist seg at fokusgrupper er godt egnet til å undersøke holdninger, erfaringer og meninger $(16,17)$. Gjennom fokusgruppediskusjoner ønsket vi å fange opp legenes ulike ideer og holdninger til det valgte temaet.

En fokusgruppe består gjerne av 6-10 deltakere og ledes av en eller to «mediatorer» (gruppeledere). Fokusgruppemetoden skiller seg fra vanlige intervjuer ved at meningene $i$ en fokusgruppe til dels dannes underveis gruppediskusjonen. For mer om metoden se Liamputtong (16) og Malterud (17).

Fokusgruppesamtalene foregikk på tre nasjonale grunnkurs i psykiatri, arrangert på ulike steder i landet. På grunn av deltakelsen på grunnkursene var legene noe kjent med hverandre på forhånd, men de var ikke nære bekjente - det er anbefalt ved fokusgruppeintervjuer at deltakerne ikke kjenner hverandre personlig, som venner, da dette er antatt å kunne hemme en fri og kritisk meningsutveksling i gruppen (17).

Deltakelsen var frivillig, og undersøkelsen ble anonymisert i tråd med etiske retningslinjer. Informantene ble plukket ut med tanke på spredning når det gjaldt bosted, type arbeidssted og kjønn. Totalt deltok 40 leger, 24 norske og 16 utenlandske. Kursdeltakerne fikk både muntlig og skriftlig informasjon om prosjektet. Samtlige ga samtykke til å delta i undersøkelsen. Det var god spredning når det gjaldt opprinnelsesland blant de uten- landske legene - de kom fra Skandinavia, Nord-Europa, Øst-Europa, Midtøsten og Sørøst-Asia.

Det ble gjennomført i alt fem fokusgrupper, hver med 6-10 deltakere. På de to første grunnkursene hadde vi separate samlinger for henholdsvis norske og utenlandske leger, til sammen fire grupper. Gruppen på det tredje grunnkurset valgte vi å ha blandet for å se om vi da fikk frem andre holdninger og meninger.

Utvelgelsen til de enkelte gruppene ble foretatt ut fra etternavn (etnisk fremmedklingende etternavn og norske etternavn). Ingen av legene som deltok, definerte seg ut av den gruppen de ble plassert inn i. Årsaken til at en slik gruppeinndeling ble valgt, var erfaringene fra internasjonale studier, som viser at gruppehomogenitet er viktig for å få frem holdninger og skape gode diskusjoner (17). Vi fryktet at legene ville bli mer forsiktige i sine uttalelser dersom de skulle diskutere et tema som fremsto som følsomt i en gruppe sammensatt av utenlandske og etnisk norske leger.

Hver fokusgruppediskusjon varte i ca. 60 minutter. Den ble tatt opp på bånd. Gruppene ble ledet av to leger - mediatorene (førsteforfatter og andreforfatter). Vi søkte størst mulig grad å få til en fri diskusjon deltakerne imellom. De ble først spurt om egne erfaringer som utenlandsk lege/egne erfaringer med utenlandske kolleger. Deretter ble de spurt om sitt syn på behovet for en mentorordning og om hvordan en slik ordning eventuelt burde utformes.

Umiddelbart etter hver gruppesamtale ble inntrykk fra samtalen utvekslet mellom de to mediatorene. Lydfilene ble transkribert og skrevet ut og så slettet. Navn på gruppedeltakerne ble ikke notert eller lagret, og utsagn fra lydfilene kunne ikke knyttes til en bestemt person.

\section{Analyse}

Det transkriberte materialet ble analysert ved hjelp av tematisk analyse $(17,18)$. Hvert fokusgruppeintervju ble gjennomlest i detalj og utsagn kodet på anbefalt systematisk og trinnvis måte. Deretter ble intervjuene sammenholdt.

Vi gjennomsøkte hele datasettet for å finne gjentatte meningsmønstre, og temaene ble tolket $\mathrm{i}$ tråd med gjeldende prinsipper $(18,19)$. Intervjuene ble i tillegg uavhengig analysert av tredje- og sisteforfatter, som begge er vitenskapelig skolert. Innholdskodingen, temaene og fortolkningene ble deretter sammenliknet og diskutert i den samlede forskergruppe inntil konsensus var oppnådd. Det fremkom små forskjeller.

\section{Resultater}

Analysen viste at det var to gjennomgående temaer som til sammen la grunnlaget for legenes syn på behovet for en mentorordning: opplevde kommunikasjonsproblemer og holdninger og verdier. Hvert av hovedtemaene hadde igjen undertemaer.

\section{Kommunikasjon}

Språkproblemer. De norske legene mente at språkkompetansen til de utenlandske legene var dårligere enn det de utenlandske legene selv mente den var. De hadde ofte vansker med å forstå språket og uttalen til sine utenlandske kolleger og hadde opplevd at mange ikke forsto norsk godt nok. De hadde observert at slike problemer også gikk igjen i kommunikasjonen med pasientene.

Problemer oppsto særlig når utenlandske leger skulle overbringe beskjeder per telefon eller skrive journalnotater. Manglende forståelse av meningsinnhold var vanskeligst å oppdage, mente de, dette ble ofte først erfart i klinisk samarbeid.

Språk! Det synes jeg er et betydelig problem, som jeg har kjent på hele tiden - frustrasjonen hos pasienter som heller vil søke seg til en norsk lege $i$ utdanning enn til en utenlandsk overlege ... De kan vare veldig flinke som leger, men så er det kommunikasjonen, da!

Selv om det også blant de utenlandske legene var enkelte som erkjente at det kunne være språkproblemer, mente de fleste at de var små og ubetydelige - noen hevdet ikke-eksisterende. De opplevde at de var «like gode som alle andre» og mente at de norske språkkravene var altfor strenge. Flere tok den obligatoriske språktesten som de hadde gjennomført som bevis på at de ikke hadde språkproblemer:

Kan jeg spørre deg: finnes det ikke noen grense!? Skal jeg holde på i tre år, fem år?? Kommer jeg til å snakke på samme måte som deg? Nei!

Kulturproblemer. De norske legene hadde erfart at utenlandske kolleger kunne misforstå den norske væremåten. De kunne tolke kliniske situasjoner forskjellig fra det de selv gjorde, legge vekt på andre ting $\mathrm{i}$ behandlingen og ha annerledes faglige vurderinger. Noen hadde også erfart ulikheter i kvinnesyn hos leger fra ikke-vestlige land og manglende aksept for kvinnelige ledere. Dette forklarte de med kulturforskjeller. Det var likevel en viss usikkerhet når det gjaldt å bedømme hva som skyldtes kulturforskjeller og hva som skyldtes personlighetstrekk hos den enkelte lege.

Blant de utenlandske legene var det få som opplevde at de hadde problemer med å forstå norsk kultur. Flere hevdet at kulturforskjellene i verden i dag er mindre enn tid- 
ligere og advarte mot kulturstereotypier hos norske kolleger.

\section{Holdninger og verdier}

Hjelpsøking. Idealet om å klare seg selv. På spørsmål om det var ønskelig med spesielle støtteordninger for utenlandske leger, kom det i gruppene med utenlandske leger frem en tydelig greie-seg-selv-holdning. Idealet syntes å være uavhengighet av andre. Å spørre om hjelp ble oppfattet som å ligge andre til byrde, og det ble opplevd som en svakhet å være avhengig av andres støtte. Da ville man heller konsultere ordbøker og internett.

Da kommer jeg tilbake til den grunnholdningen at man skal klare seg selv. Altså, man må loere å klare seg og å stå på egne bein. Og skaffe seg informasjon på egen hånd.

Mange mente at selvstendighet var et personlighetstrekk som karakteriserte mange utenlandske leger og som bidro til at de hadde migrert og nådd så langt som de hadde.

Egen legerolle. De fleste av de utenlandske deltakerne betraktet legen som øverst i et hierarkisk system og ønsket å opprettholde denne statusen. Legerollen innebar at det var de som veiledet og støttet andre og gjennom dette markerte sin kompetanse. $\AA$ motta hjelp og veiledning var vanskelig.

Noen reagerte ellers på det norske psykiske helsevesenet, hvor legene ofte arbeider på samme nivå som sykepleiere og ikkemedisinske faggrupper. De kunne finne dette ydmykende. De norske legene, derimot, var vant til å arbeide $\mathrm{i}$ en kultur som, sammenliknet med andre kulturer, er ganske egalitær.

Holdninger til kolleger med annen etnisk bakgrunn. Etnisk integrering versus utstøting/isolering. Erfaringene til flere av de norske legene var at de selv ofte kunne være lite inkluderende og velge bort sine utenlandske kolleger fra sitt privatliv. De utenlandske legene opplevde på sin side at det var viktig for dem å unngå å isolere seg. De mente at arbeidsmiljøet burde være mer sosialt inkluderende, og flere ga uttrykk for at de følte seg uønsket - de var ønsket kun så lenge det var behov for arbeidskraften deres.

Det at vi utgjør en stor ressurs, er ikke det bildet som landet selger til oss. Alle signaler vi får fra utdanningskomiteen og Legeforeningen er at de ikke vil ha oss. Kanskje vi må begynne der?

Unngåelse av konflikter. Ikke-konfronterende holdninger. Manglende språk- og kulturkompetanse hos utenlandske kolleger var for de norske legene et svært følsomt tema. De vegret seg for å påpeke problemer av frykt for konflikter.
... fordi da er man redd for plutselig å bli beskyldt for å vaere rasist og man er jo imot rasisme. Man tør ikke å si: Du fungerer ikke, du kan ikke nok språk.

\section{Behovet for en mentorordning}

På direkte spørsmål om det var behov for en mentorordning for utenlandske leger, mente de fleste av disse at dette ikke var nødvendig. Utfordringene med språk og kultur var ikke større enn at de taklet det selv. Dersom det oppsto problemer, kunne de heller spørre noen de hadde tillit til - dersom de følte for det. Enkelte tok likevel til orde for at en mentorordning kunne være nyttig, men da først og fremst som hjelp med praktiske og administrative oppgaver

Selvfølgelig kan noen ha behov i begynnelsen - vi er nye i Norge. Men da jeg var ny, var min sykepleier, min kamerat og min veileder til stede for meg. Det er ikke nødvendig a lage et slikt tiltak, som egentlig er mest for a fremvise en ting som et stort problem, som egentlig ikke er et problem.

Forslaget om en mentorordning ble av mange utenlandske leger opplevd som en overreaksjon fra norske kolleger som ikke kjente deres situasjon. Det ble beskrevet som «dumt og nedvurderende». De mente at problemet lå hos noen ganske få uegnede utenlandske leger, og at dette så ble generalisert til å gjelde alle.

Også enkelte av de norske legene var usikre på det reelle omfanget. Likevel opplevde de fleste at språk- og kulturrelaterte problemer gjaldt mange utenlandske leger og fant det problematisk at det ofte ikke ble erkjent av disse selv. De ønsket derfor en mentorordning velkommen. Et problem som ble trukket frem av flere, var at arbeidsgiveren satte legene raskest mulig «i produksjon», uten å investere i nødvendig språk- og kulturopplæring.

Det var enighet på tvers av gruppene om at en mentorordning kunne ha en viktig sosial funksjon. Ordningen ble sett på som en mulighet til å få etablert et sosialt kollegialt nettverk på tvers av kulturell tilhørighet og til å skape et forum for gjensidig kulturell berikelse. Videre ville en mentorordning kunne være egnet til å ta opp relasjonelle konflikter som ellers ville forbli underkommunisert.

\section{Innhold, implementering}

\section{og organisering av en mentorordning}

Deltakerne ble til slutt stilt spørsmål om hvordan en eventuell mentorordning for utenlandske leger best kunne organiseres. Temaene som kom frem dreide seg om innhold, implementering, organisering, med følgende undertemaer.
Definering og avgrensning av innhold og mål. De fleste av dem som gikk inn for en mentorordning, mente at man måtte utarbeide et konkret innhold og en klar målsetting. Mange mente at denne typen veiledning burde skilles fra vanlig opplæring i prosedyrer, rutiner og journalarbeid, som heller burde gis i form av et generelt introduksjonskurs for alle nyansatte leger. Ren språkopplæring burde heller ikke drives innenfor en slik mentorordning, men som egne kurs. Innholdsmessig burde man i hovedsak legge vekt på kommunikasjonsproblemer og sosiokulturell støtte.

Horisontal versus vertikal organisering. De fleste av legene i de norske gruppene argumenterte for at mentor og den utenlandske legen burde være på samme nivå i hierarkiet - det vil si at underordnet lege veiledet underordnet lege (horisontal organisering).

Mange av de utenlandske legene reagerte på at kolleger på samme kompetansenivå skulle være mentor. Flere mente det ville være ydmykende å bli veiledet av annen lege i utdanning, en som kanskje var kommet kortere i utdanningsløpet enn det de selv var. De ville foretrekke en overlege som mentor - en som var høyere i hierarkiet, med mer status og større fagkompetanse enn det de selv hadde (vertikal organisering).

Inkorporering av en mentorordning $i$ eksisterende supervisjonsordning. Flere mente at de kliniske veilederne (overlegene) i tillegg kunne ha en mentorrolle overfor utenlandske kandidater. Veiledningen burde da ha et eksplisitt tilleggsinnhold, med mulighet for å ta opp språklige, kulturelle og sosiale problemer. Ett av argumentene for denne typen organisering var at det er i den kliniske veiledningen språklige og kulturelle problemer $\mathrm{i}$ arbeidet først oppdages. Overlegens vidererapportering av slike problemer ville dessuten ikke utløse samme lojalitetskonflikt som hvis en sideordnet kollega måtte ta dem opp.

Mentorordning organisert som gruppeveiledning. Det kom også frem forslag om å organisere en felles mentorordning for flere arbeidsplasser, som gruppesamlinger. Både de norske og de utenlandske legene støttet en slik ordning. Man mente at den ville redusere antallet mentorer og at det også ville by på fordeler at veiledningen kunne foregå mer konsentrert og utenfor klinikken. Spesielt ville utenlandske leger da kunne utveksle nyttige erfaringer fra arbeidssituasjonen seg imellom.

\section{Diskusjon}

Omfanget av kommunikasjonsproblemer og behovet for en mentorordning

Et slående funn i denne undersøkelsen er at de norske legene opplevde kommunikasjonsproblemene til de utenlandske legene 
som større enn det de utenlandske legene selv gjorde. Dette sammenfaller med funnet fra den nasjonale undersøkelsen som Overlegeforeningen tidligere gjennomførte (6). I begge undersøkelser er det i hovedsak de norske legene som mener at det er behov for en støtteordning for utenlandske leger, ikke de utenlandske legene selv.

Én forklaring kan være at de norske legene generaliserer og tillegger en hel gruppe (dvs. utenlandske leger) dårlig språk- og kulturkompetanse, mens det i realiteten gjelder noen få. Stereotypier og generaliseringer er kjente menneskelige fenomener. I tillegg kan utenlandske leger stå i fare for å bli vurdert mer kritisk enn enn de norske. Svikt og uhell vil dermed kunne overdrives. For eksempel kan en av årsakene til at utenlandske leger synes å være overrepresentert i klagesaker, være at de er mer utsatt for å utløse klager - de er lettere å ta enn de norske (20).

På den annen side er det også et menneskelig fenomen å fortolke virkeligheten slik at den styrker ens egen selvfølelse. Det kan være truende å ta innover seg språklig og kulturell tilkortkommenhet, ikke minst hvis det kan ha betydning for karrieren. I tillegg kan det for alle være vanskelig å bedømme hvordan man fungerer sammen med og kommuniserer med andre. En lege kan oppleve kommunikasjonen med en pasient som god, mens pasienten kan oppleve den som dårlig. Dette er vist i norske behandleres møte med pasienter fra minoritetskulturer, for eksempel den samiske (21).

\section{Synet på en mentorordning}

\section{og hvordan den bør organiseres}

Mange av de utenlandske legene avviste at norske leger i spesialisering skulle gå inn som mentor for dem, det betraktet de som nedverdigende og ydmykende. Dette samsvarer med funn internasjonalt, blant annet fra Storbritannia, som peker på at stolthet, redsel for å tape ansikt og en opplevelse av konstant å være under oppsikt kan være barrierer mot læring på arbeidsstedet (14).

En alternativ løsning ville være å la mentorordningen inngå i den allerede eksisterende obligatoriske veiledningsordningen for leger i spesialisering, slik at den kliniske veilederen i tillegg hadde en mentorfunksjon for utenlandske leger. I litteraturen er ikke en slik organisering omtalt. Årsaken kan være at mentorordninger gjerne er beskrevet innenfor spesialiteter som ikke har like formaliserte og tette veiledningsordninger som psykiatrien.

I internasjonale studier der man har undersøkt organisering av mentorordninger for utenlandske leger, anbefales en detaljert beskrivelse av mentors rolle og oppgaver og grundig opplæring av dem som påtar seg en slik rolle (9). Liknende anbefalinger ble gitt av informantene i vår studie - funnene samsvarer dermed godt med funn $\mathrm{i}$ andre studier.

Flere av legene - især de utenlandske gikk inn for en frivillig ordning der mentor fortrinnsvis blir utpekt av veiledningskandidaten. Dette er i tråd med anbefalinger fra noen internasjonale studier (9). Problemet med en slik frivillig ordning er at det kan være vanskelig å fange opp alle med behov. Ut fra holdningene som kom frem i gruppene med utenlandske leger, kan en slik bekymring muligens være reell.

\section{Studiens begrensninger og styrke}

Funn som fremkommer gjennom fokusgrupper er, i likhet med funn fra andre typer kvalitative studier, ikke generaliserbare til en større gruppe. De kan likevel gi viktig innsikt i folks opplevde virkelighet og et bilde av holdninger og meninger som styrer deres atferd $(16,17)$. Vår studie må betraktes som eksplorativ og har ikke som mål å gi en fullstendig beskrivelse. Andre informanter og en annen gruppesammensetning ville kunne gitt andre funn. Det samme kunne andre kvalitative metoder gjort, som for eksempel deltakende observasjon eller individuelle dybdeintervjuer.

En metodisk svakhet er at de to mediatorene ikke tidligere hadde erfaring med å lede fokusgrupper. Det kan derfor tenkes at kvaliteten i materialet som fremkom ville blitt bedre hvis de hadde vært mer erfarne. På den annen side var hovedmediator en erfaren psykiater med kompetanse på gruppedynamikk, og begge mediatorer ble veiledet underveis i prosessen av forskerkompetent kollega innen kvalitativ forskning (sisteforfatter).

En annen begrensning er at dataanalysen kun var en tematisk analyse av innholdet $\mathrm{i}$ diskusjonene og ikke omfattet analyse av selve samhandlingssituasjonen og konteksten. Dette kan ha svekket fortolkningene. Det skal allikevel bemerkes at de fleste fokusgruppeanalyser som gjøres i studier internasjonalt er, på samme måte som $\mathrm{i}$ vår studie, rene innholdsanalyser $(18,19)$.

Det kan videre innvendes at våre informanter kun besto av leger og at studien ikke inkluderte pasienter eller sykehusadministratorer. $\AA$ inkludere flere informantgrupper i studien ville gitt en mer fullstendig forståelse av problematikken og muligens generert flere ideer. På grunn av knapphet på ressurser og tid var det dessverre ikke mulig å få til en mer omfattende design.

En vesentlig metodisk styrke i vår studie er at kodingen, temaene og fortolkningen av materialet ble foretatt individuelt av alle medforfatterne og deretter sammenliknet og drøftet i hele gruppen inntil konsensus var oppnådd. At forfatterne selv hadde ulik kulturell bakgrunn, og at tredje- og sisteforfat- ter hadde vitenskapelig kompetanse, styrker validiteten.

\section{Konklusjon}

Denne kvalitative studien støtter tidligere funn som viser at utenlandske legers språkog kulturkompetanse vurderes forskjellig av de norske og de utenlandske. De utenlandske legene $\mathrm{i}$ studien syntes selv at de hadde få problemer. De var derfor overveiende skeptiske eller avvisende til en mentorordning. Det kom også frem holdningsmessige barrierer hos målgruppen mot organiserte støtteordninger.

Vi takker alle deltakerne i gruppene. Takk også til Norsk psykiatrisk forening for økonomisk bistand og til Pål Abrahamsen, Victoria Akre og Ann Færden for gjennomlesing av manuskriptet og for gode råd.

\section{Morten Sandbu (f. 1955)}

er spesialist i psykiatri og overlege. Han har vært medlem i utvalg for transkulturell psykiatri i Norsk psykiatrisk forening siden 2008. Forfatter har fylt ut ICMJE-skjemaet og oppgir ingen interessekonflikter.

\section{Anne Kamps (f. 1979)}

er overlege. Hun var LIS-medlem i utvalg for transkulturell psykiatri, Norsk psykiatrisk forening, i perioden 2010-12

Forfatter har fylt ut ICMJE-skjemaet og oppgir ingen interessekonflikter.

\section{Valjbona Preljevic (f. 1969)}

er spesialist i psykiatri og overlege, med spesiell erfaring innen psykosomatikk og transkulturell psykiatri. Hun har forskerkompetanse og er i ferd med å avslutte sin ph.d.

Forfatter har fylt ut ICMJE-skjemaet og oppgir ingen interessekonflikter.

\section{Cecilie Jávo (f. 1948)}

er dr.med., spesialist i psykiatri og i barne- og ungdomspsykiatri og assisterende avdelingsoverlege. Hun har i mange år arbeidet med kulturrelatert forskning og har ledet utvalg for transkulturell psykiatri i Norsk psykiatrisk forening siden 2008

Forfatter har fylt ut ICMJE-skjemaet og oppgir ingen interessekonflikter.

\section{Litteratur}

1. Mullan F. The metrics of the physician brain drain N Engl J Med 2005; 353: 1810-8.

2. Den norske legeforening. Årsmelding 2014 http://legeforeningen.no/fagmed/norskpsykiatrisk-forening/arsmotet/arsmotet-2015/ arsmelding-2014---norsk-psykiatrisk-forening/ (7.5.2015). 
3. Díaz E, Hjörleifsson S. Immigrant general practitioners in Norway: a special resource? A qualitative study. Scand J Public Health 2011; 39: 239-44.

4. Suurmond J, Seeleman C. Shared decisionmaking in an intercultural context. Barriers in the interaction between physicians and immigrant patients. Patient Educ Couns 2006; 60: 253-9.

5. Ulrey KL, Amason P. Intercultural communication between patients and health care providers: an exploration of intercultural communication effectiveness, cultural sensitivity, stress, and anxiety. Health Commun 2001; 13: 449-63.

6. Aasland OG, Javo C, Larsen A. Utenlandske leger ved norske sykehus. Tidsskr Nor Lægeforen 1997; 117: 4246-50.

7. Chen PG Curry LA, Bernheim SM et al. Professional challenges of non-U.S.-born international medical graduates and recommendations for support during residency training. Acad Med 2011. 86: $1383-8$.

8. Hall P, Keely E, Dojeiji S et al. Communication skills, cultural challenges and individual support: challenges of international medical graduates in a Canadian healthcare environment. Med Teach 2004; 26: 120-5.

9. Lockyer J, Fidler H, De Gara C et al. Mentorship for the physician recruited from abroad to Canada for rural practice. Med Teach 2010; 32: e322-7.

10. Curran V, Hollett A, Hann S et al. A qualitative study of the international medical graduate and the orientation process. Can J Rural Med 2008; 13: $163-9$.

11. Steven A, Oxley J, Fleming WG. Mentoring for NHS doctors: perceived benefits across the personalprofessional interface. J R Soc Med 2008; 101 : $552-7$

12. Elkin JA. Review of mentoring relationships: formation, function, benefits and dysfunction. Otago Management Graduate Review 2006; 4: 11-23.

13. Pilotto LS, Duncan GF, Anderson-Wurf J. Issues for clinicians training international medical graduates: a systematic review. Med J Aust 2007; 187: 225-8.

14. Mahajan J. Stark P. Barriers to education of overseas doctors in paediatrics: a qualitative study in South Yorkshire. Arch Dis Child 2007; 92: 219-23.

15. Sockalingam S, Hawa R, Al-Battran M et al. Preparing international medical graduates for psychiatry residency: a multi-site needs assessment. Acad Psychiatry 2012; 36: 277-81.

16. Liamputtong P. Focus group methodology. Principles and practice. Thousand Oaks, CA: Sage Publications, 2011.

17. Malterud K. Fokusgrupper som forskningsmetode for medisin og helsefag. Oslo: Universitetsforlaget, 2012.

18. Braun V, Clarke V. Using thematic analysis in psychology. Qual Res Psychol 2006: 3: 77-101.

19. Krueger RA. Analyzing \& reporting focus group results. Focus Group Kit 6. Thousand Oaks, CA: Sage Publications, 1998.

20. Hauff E, Kumar B. Hvordan kan legens språkforståelse og kulturelle bakgrunn påvirke risikoen for feil? I: Bratland SZ, Lundevall S, red. Læring av feil og klagesaker. Rapport fra Helsetilsynet 7/2009 Oslo: Helsetilsynet, 2009: 73-81.

21. Sørlie T, Nergård JI. Treatment satisfaction and recovery in Saami and Norwegian patients following psychiatric hospital treatment: a comparative study. Transcult Psychiatry 2005; 42: 295-316.

Mottatt 10.6. 2014, første revisjon innsendt 7.12.

2014, godkjent 29.4. 2015. Redaktør: Tor Rossnes. 